NBSIR 82-2632

A Review of the Bituminous Reference Sample Program of the AASHTO Materials Reference Laboratory

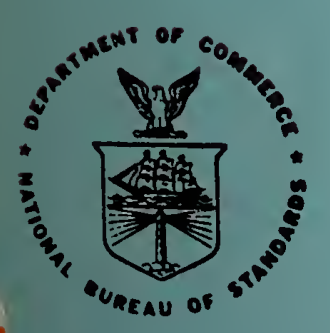



NBSIR 82-2632

\section{A REVIEW OF THE BITUMINOUS}

REFERENCE SAMPLE PROGRAM OF THE

AASHTO MATERIALS REFERENCE

LABORATORY

Peter A. Spellerberg

J. York Welborn

January 1983

U.S. DEPARTMENT OF COMMERCE, Malcolm Baldrige, Secretary NATIONAL BUREAU OF STANDARDS, Ernest Ambler, Director 



\section{ABSTRACT}

The Bituminous Reference Sample Program of the AASHTO Materials Reference Laboratory (AMRL) has been in operation for more than fifteen years. It is one of four sample programs conducted as a cooperative undertaking between the National Bureau of Standards and the American Association of State Highway and Transportation Officials (AASHTO). This paper provides an overview of accomplishments of this program.

In this paper information is presented on the development of standard specifications and test methods, the AASHTO, and the AMRL. Details concerning the operation of the Bituminous Reference Sample Program are reviewed. The value of the laboratory rating system and the laboratory performance charts which have been developed are discussed. Conclusions are made regarding the effectiveness of the program and the accuracy of established test precision limits.

KEYWORDS: Asphalt Cement, Cutback Asphalt, Laboratory Performance, Reference Sample 


\section{ACKNOWLEDGEMENTS}

The authors gratefully acknowledge the contributions of Mr. John R. Dise in the preparation of this report. 
1. EVENTS LEADING TO THE ESTABLISHMENT OF THE PROGRAM------------- 1

1.1 Early Development of Specifications and Tests for Road Materials-- 1

1.2 Origin of AASHTO Standard Specifications on Methods of Test---------------- 1

1.3 The AASHTO Materials Reference Laboratory (AMRL)---------- 2

2. THE BITUMINOUS REFERENCE SAMPLE PROGRAM--

2.1 Frequency of Sample Distribution------------------------ 2

2.2 Grades of Bituminous Materials Analyzed------------------- 3

2.3 Participation in the Program-- 3

2.4 Preparation of Samples------------------------------- 3

2.5 Testing Program for Participating Laboratories-_-_-_-_-_-_ 3

2.6 Techniques Used to Analyze Test Data------------ 4

2.7 Storage and Preliminary Analysis of Data---_-_-_-_-_-- 4

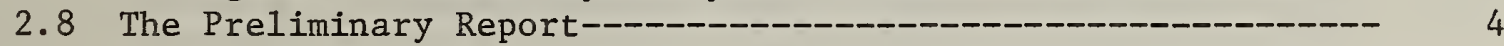

2.9 The Final Report--

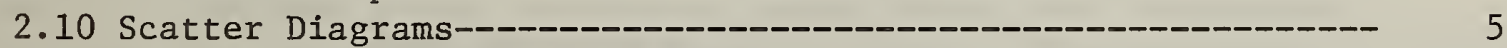

2.11 Laboratory Performance Charts- 5

3. DISCUSSION OF RESULTS--- 6

3.1 Causes of Variable Results--- 6

3.2 Change in the Coefficient of Variation--_---_-_-------- 7

3.3 Continuous vs Limited Participation--_--_--_---_-------- 8

3.4 Coefficients of Variation for Cutback Asphalts-_--_-_---- 9

4. BENEFITS PROVIDED BY THE PROGRAM-- 10

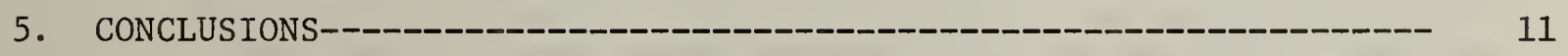

6. REFERENCES-- 12 
Table 1. Bituminous Reference Sample Program

Figure 1. Youden Scatter Diagram for Viscosity at $60^{\circ} \mathrm{C}------------14$

Figure 2. Performance Charts for Six Laboratories Showing Normal Deviates for the Kinematic Viscosity of Asphalt Cements at $135^{\circ} \mathrm{C}-$

Figure 3. Performance Charts for Six Test Properties

Obtained from Two Different Laboratories---16

Figure 4. Coefficients of Variation for Viscosity at $60^{\circ} \mathrm{C}$ During Ten Years of Laboratory

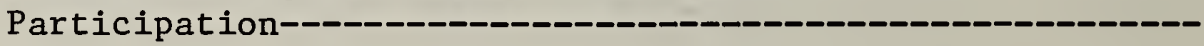

Figure 5. Coefficients of Variation for the Penetration Test

Original Asphalt Cements and Thin Film Residues--------- 18

Figure 6. Comparison of the Coefficient of Variation for Kinematic Viscosity at $135^{\circ} \mathrm{C}$ - Continuous and Limited Participation Groups-----------

Figure 7. Comparison of the Coefficient of Variation for Viscosity Tests on the Original and Distillation Residues for Cutback Asphalts------------------- 


\title{
A REVIEW OF THE BITUMINOUS REFERENCE SAMPLE PROGRAM OF THE
}

\author{
AASHTO MATERIALS REFERENCE LABORATORY
}

\section{EVENTS LEADING TO THE ESTABLISHMENT OF THE PROGRAM}

\subsection{Early Development of Specifications and Tests for Road Materials}

In 1911 the Office of Public Roads and Rural Engineering (OPRRE) of the $U$. S. Department of Agriculture published Bulletin No. 38 giving the first description of specifications and test methods for bituminous road construction materials. Bulletin No. 38 was later revised and published as Bulletin No. 314. In 1916 a survey of State Highway Departments by the OPRRE determined that less than one half of the states had proper facilities for testing highway construction materials. Some states did not have any facilities [1]. A majority of the states indicated their willingness to cooperate with the OPRRE and tentatively agreed to send representatives to a conference on materials used in highway work.

In 1917, as a result of the information gathered at the conference, the OPRRE published Bulletin No. 555 "Standard Forms for Specifications, Tests, Reports, and Methods of Sampling Road Materials." This bulletin covered aggregates, Portland Cement, concrete, paving brick, and bituminous materials. In 1918 the OPRRE published Bulletin 691 "Typical Specifications for Bituminous Materials" and Bulletin 704 "Typical Specifications for NonBituminous Road Materials".

\subsection{Origin of AASHTO Standard Specifications and Methods of Test}

The American Association of State Highway officials (AASHO) was organized in 1914. After several meetings, the members concluded, in 1919, that a need existed for uniform standard methods of testing and a Committee on Tests and Investigations was formed. Representatives from the states and the Bureau of Public Roads (BPR), (the BPR became the new title for the OPRRE), met in 1921 to standardize the work of the state highway departments and the Bureau's laboratories. This marked the beginning of the AASHO Committee on Materials. Bulletin 949 published by BPR in 1921 was the first set of standards recommended by the Committee on Materials.

In 1924 the methods included in BPR Bulletin 1216 which superceded Bulletin 949 were adopted as an AASHO standard. This standard remained in effect until 1931 when it was superseded by the first edition of "Tentative Standard Specifications for Highway Materials and Methods of Sampling and Testing."

During the sixties and early seventies many State Highway Departments became Departments of Transportation. This conversion was the result of the State Highway Departments taking on additional responsibilities in areas of transportation other than highways. In recognition of this, AASHO changed 
its name to the American Association of State Highway and Transportation officials (AASHTO) in 1973.

In addition to the early work by the OPRRE and the State Highway Departments, The American Society for Testing and Materials (ASTM) played an important role in the standardization of test methods and specifications. ASTM Committee D4 on Road and Paving Materials was formed in 1903. Many AASHTO representatives are members of this ASTM committee. For this reason, AASHTO generally adopts ASTM standards. In cases where the AASHTO standards are similar but not technically identical to ASTM methods, the differences are noted in footnotes in the AASHTO Book of Standards, Part 1 Specifications and Part II - Methods of Sampling and Testing.

\subsection{The AASHTO Materials Reference Laboratory (AMRL)}

Based on experience gained from a long involvement with the activities of the ASTM Cement and Concrete Reference Laboratory, the American Association of State Highway Officials proposed in 1961 that a Materials Reference Laboratory, sponsored by the Committee on Materials, be established for standardizing and improving the precision and reliability of test methods. The AMRL began activities at the National Bureau of Standards in 0ctober 1965. Its primary responsibilities were and still are to promote uniformity in the testing of construction materials and to improve the quality of test results.

The four principal functions of the AMRL are: (1) Inspection of materials testing laboratories subscribing to the service, (2) Distribution of proficiency test samples to subscribers, (3) Study of testing problems, and (4) Participation in the work of technical committees. An overview of the AMRL is presented in a paper by steele [2].

The remainder of this report is limited to a review of the second function mentioned above, concentrating on the Bituminous Reference Sample Program, one of four reference sample programs. It provides examples of the activities and benefits associated with all the programs.

\section{THE BITUMINOUS REFERENCE SAMPLE PROGRAM}

\subsection{Erequency of Sample Distribution}

The Bituminous Reference Sample Program includes both asphalt cements (AC) and cutback asphalts (CB). Since 1970, a matched pair of asphalt cement samples has been distributed to participants twice a year (in March and September). Prior to 1970, samples were not distributed at regular intervals. Since 1973, a pair of cutback asphalt samples has been distributed in June of each year. Prior to 1973, four pairs of cutback asphalts were sent out at approximately six month intervals over a one and one half year period starting in August 1967 and ending in March 1969. 


\subsection{Grades of Bituminous Materials Analyzed}

In the testing program, the same grade of asphalt was not distributed at every interval. Instead, a variety of grades were used (see Table 1) including penetration graded asphalt, original viscosity graded asphalt and residue viscosity graded asphalt. For example, penetration graded asphalt cements have included $60 / 70,85 / 100,120 / 150$ and $200 / 300$ grades. Asphalt cements graded on the original viscosity included $\mathrm{AC}-10$ and $\mathrm{AC}-20$ grades. Asphalt cements graded on the viscosity of the residue from the rolling thin film oven test included four samples of the AR-2000 grade. Cutback asphalts included MC250, MC70, MC30, and RC250 grades. Details concerning each pair of samples distributed are shown in Table 1.

\subsection{Particioation in the Program}

The number of laboratories receiving asphalt cements has increased from 53 at the beginning of the program to 132 laboratories. The number of laboratories receiving cutback asphalts has increased from 63 to 127.

The types of laboratories participating in the program include State Highway and Federal test laboratories, producer and commercial test facilities, and municipal, university, and national testing agencies. Most of the participants are located in the United States or Canada. However, some registrants are located in Central and South America and South Africa.

\subsection{Preparation of Samples}

The bituminous reference sample program was the first program selected for implementation by the AMRL because of the relatively small amount of effort required to prepare test samples. The bulk material for the first pair of samples was obtained in five-galion $(20 \mathrm{~L})$ containers. The asphalt was processed and test specimens prepared and packaged at the Federal Highway Administration (FHWA) Fairbanks Highway Research Station located in Langley, Virginia.

All subsequent pairs of reference samples were prepared by AMRL personnel at the National Bureau of Standards according to the guidelines recommended by the FHWA. As the participation in the program increased, two 55-gallon (220 L) drums were used to acquire bulk material (one drum for each sample of the pair). Preparation of a typical pair of test samples involves heating and blending the asphalt material in 55-gallon (220 L) drums and quickly dispensing it into one-quart ( $1 \mathrm{~L}$ ) friction top cans (screw top cans are used for cutbacks). Two one-quart (1 L) cans, one drawn from each of the two 55-galion (220 L) drums, are then packaged together in a parcel weighing about three kilograms. These quart $(1 \mathrm{~L})$ cans are then distributed to participants.

\subsection{Testing Program for Participating Laboratories}

Pairs of reference samples are tested by the latest AASHTO or ASTM Test Methods. A data form listing the tests to be made and special instructions for testing and reporting the data accompany each pair of reference samples. The following are included in the program: 


\section{Bituminous Asphalt Cement}

Penetration of Bituminous Materials, $25^{\circ} \mathrm{C}$

Flash Point by Cleveland Open Cup, $\left({ }^{\circ} \mathrm{C}\right)$

Solubility of Bituminous Materials in Organic Solvents

Specific Gravity of Bituminous Materials

Kinematic Viscosity of Asphalts, $135^{\circ} \mathrm{C}$

Viscosity of Asphalts, T202, $60^{\circ} \mathrm{C}$

Effect of Heat and Air on Asphalt Materials (Thin Film Oven Test)

Effect of Heat and Air on a Moving Film of Asphalt (Rolling

Thin Film Oven Test)

Penetration of the Residue, $25^{\circ} \mathrm{C}$

Kinematic Viscosity of the Residue, $135^{\circ} \mathrm{C}$

Viscosity of the Residue, $60^{\circ} \mathrm{C}$

\section{Cutback Asphalt}

Kinematic Viscosity of Asphalts, $60^{\circ} \mathrm{C}$

Flash Point with Tag Open-Cup Apparatus, $\left({ }^{\circ} \mathrm{C}\right)$

Distillation of Cutback Asphaltic (Bituminous) Products, T78

Penetration of the Residue, $25^{\circ} \mathrm{C}$

Kinematic Viscosity of the Residue, $135^{\circ} \mathrm{C}$

Viscosity of the Residue, $60^{\circ} \mathrm{C}$

\subsection{Techniaues Used to Analyze Test Data}

Analysis of test data is based on the paired-sample system described in papers by Youden [3] and Crandall and Blaine [4]. The analysis of test data is performed using a computer program developed by $H$. T. Arni.

\subsection{Storage and Preliminary Analysis of Data}

To prepare the data for analysis, data for each laboratory is entered into a mass storage file and coded with laboratory numbers, sample pair numbers, test numbers and other pertinent information such as the standard test method used. This data is then sorted and a statistical analysis for each test property made.

The first step in the analysis is to remove from consideration any test values which can be justifiably considered invalid. In removing outliers a trial computer run is executed which repeatedly eliminates data beyond three standard deviations. The test data to be eliminated are selected based on the results of this trial run, the shape of the normal curve, specific guidelines for the removal of outliers, and the statistics from previous pairs of samples. Once the outliers have been selected the data are reanalyzed to develop valid data for averages, standard deviations and coefficients of variation.

\subsection{The Preliminary Report}

A preliminary report is prepared and distributed to each participating laboratory approximately six weeks after test samples are mailed. The report shows the number of laboratories reporting test data at that time, the average values, standard deviations, and coefficients of variation on 
each of the tests included in the testing program. The purpose of this report is to provide the participating laboratories with information for identifying abnormal test results.

\subsection{The Final Report}

As soon as possible after all of the test data are received and a statistical analysis is completed, an individualized final report is prepared giving: (1) the results of tests and ratings for individual laboratories, (2) a statistical summary of results, and (3) a scatter diagram for each test property analyzed.

The results of tests by an individual laboratory are compared with the averages. Ratings are then assigned to indicate how far the laboratory's data deviate from these averages. The laboratory ratings are based on the following scale:

Rating \pm 5 , within 1.0 standard deviations of the mean; Rating \pm 4 , within 1.5 standard deviations of the mean; Rating \pm 3 , within 2.0 standard deviations of the mean; Rating \pm 2 , within 2.5 standard deviations of the mean; Rating \pm 1 , more than 2.5 standard deviations of the mean; Rating 0 , data excluded due to a large deviation.

A summation of the ratings obtained by a given laboratory over a period of time gives an indication of that laboratory's proficiency. Significance need not necessarily be attached to a single low rating or pair of ratings. A continuing tendency to get low ratings on several pairs of samples, however, indicates that a laboratory should reexamine its testing apparatus and testing procedure.

\subsection{Scatter Diagrams}

To show how individual laboratory data compares with that of other participants, scatter diagrams are prepared for each test similar to the one shown in Figure 1. For each pair of samples from each laboratory, the odd-numbered test value is plotted on the " $x$ " (horizontal) coordinate and the even-numbered test value is plotted on the "y" (vertical) coordinate. The horizontal and vertical lines represent the median values. The distance of the point from the center gives an indication of deviation from this median. A continued excessive deviation indicates some corrective action is necessary.

\subsection{Laboratory Performance Charts}

If evidence is provided that a substantial deviation in test results exists within a laboratory, that laboratory should check the testing apparatus and the procedures used by the operator. The best way of demonstrating how well the program evaluates a laboratory's testing capabilities is to study the performance charts shown in Figures 2 and 3. The horizontal axis labeled "PAIR NO." shows a scale of numbers from 1 to 10 . These numbers refer to the sequence of sample pairs distributed at six month intervals. The vertical axis labeled "NORMAL DEVIATE" gives a scale of numbers from -3.0 to +3.0 . 
Each normal deviate represents the number of standard deviations the laboratory's reported data is from the average. For example, a normal deviate of -1.7 is equivalent to a rating of -3 . A limit of +3.0 standard deviations from the average has been imposed on all data. Any data at or beyond these limits is plotted +3.0 or -3.0 on the graph. In figure 2, octagons represent the first, or odd-numbered sample, and triangles represent the second, or even-numbered sample. A graphic representation of within-laboratory precision is given in the length of the vertical lines connecting each of the sample pairs. The closer a pair of symbols for a given sample pair, the better the laboratory's repeatability. Conversely, the farther apart the symbols the greater the laboratory's random error.

The lines connecting the midpoints between each pair of symbols show the trend in the laboratory's performance over the period of time covered by the chart. Midpoints between consecutive pairs are connected with a solid line. A dashed line is used to connect midpoints if data points are missing.

The ideal situation is for a laboratory to have all symbols directly on the center line, demonstrating exceptional precision and testing accuracy. Points falling outside the range of \pm 2.0 normal deviates are usually considered suspect.

Figure 2 shows performance charts from six laboratories for the kinematic viscosity test of asphalt cement. The charts for all six laboratories are based on test data from the same ten pairs of samples.

Figure 3 shows performance charts for six test properties of asphalt cement from each of two laboratories. The charts are based on the test data from the same ten pairs of samples. Laboratory "A" shows good control for all six test properties while laboratory "B" shows poor control.

\section{DISCUSSION OF RESULTS}

\section{1 Causes of Variable Results}

It is possible that one or more of the following factors cause or contribute to the poor control shown in Figure 3:

*inexperienced operator

*deviation from standard method

*non-conformity of apparatus with specification requirements

* inaccuracy of thermometers

* lack of calibration where needed

* improper handling of sample

*improper cleaning of apparatus

*incorrect calculations 


\subsection{Change in the Coefficient of Variation}

To show how test precision varied from year to year, the coefficients of variation for the viscosity and penetration of asphalt cements and thin film residues were plotted chronologically (Figures 4 and 5 ).

Figure 4 shows the coefficients of variation for the viscosity at $60^{\circ} \mathrm{C}$ for asphalt cements and thin film residues. Only the coefficients of variation for AC-20 grade asphalt cements were plotted to minimize possible fluctuations caused by differences in the grades of asphalt cements tested. The coefficients of variation for the original asphalt cements range from about 2 to 7 percent compared to a range of 7 to 16 percent for the thin film residues. The higher values for the thin film residues are partially due to compounding test procedures and errors. The graph shows generally higher coefficients during the first four years than during the last six years of the program. This implies that the precision of test results from participating laboratories has improved as a result of participating in the program.

The ASTM multilaboratory one-sigma precision limit in percent (1S\%) for the viscosity at $60^{\circ} \mathrm{C}$ of asphalt cements and thin film residues are also shown in Figure 4.1 The precision estimate for the original asphalt cements, plotted as 3.53 percent, was calculated by dividing the ASTM multilaboratory two-sigma precision limit in percent (D2S\%), given in ASTM D2171 [6], by 2.83. The precision estimate (1S\%) for the thin film residue, plotted as 11.6 percent, is given in ASTM D1754 [7].

During the 1972 to 1976 period the coefficients of variation of the thin film residues were all above the ASTM precision estimate. From 1977 to 1982 the values were all below the ASTM estimate of precision. The data indicates that with the improved testing capability of the laboratories the ASTM precision estimates of 11.6 percent (1S\%) and 33.0 percent (D2S\%) could be lowered at least for AC-20 graded asphalt cements to 10.0 percent and 28.3 percent respectively. The coefficients of variation for the original asphalt cements are sufficiently close to the ASTM precision to warrant no change.

Figure 5 shows the coefficients of variation for the penetration at $25^{\circ} \mathrm{C}$ of the original asphalt cements and the thin film residues for all asphalt cement samples distributed between 1966 and 1981. The graph is broken into three segments: (1) Restricted Participation, (2) Open Participation $A C-20$ 's, and (3) Open Participation - Mixed Grades.

The first segment includes the coefficients of variation for six pairs of samples. These samples, which included a number of grades of asphalt cements, were distributed primarily to State Departments of Transportation before the program was open to general participation (see Table 1). The coefficients of variation indicate a general tendency toward increased

1) A description of the ASTM terms of precision applying to the test methods for construction materials is given in ASTM C670 [5]. 
precision over time for both the penetration of the original asphalt cements and thin film residues.

The second segment of the graph shows the coefficients of variation for twenty-six samples of asphalt cement distributed to participants between March 1971 and March 1977. At the beginning of this period the program was opened to general participation. The number of participants increased from 77 to 122. Except for the first four samples distributed (see Table 1, samples 21 to 24) all samples were either AC-20 or $85 / 100$ graded asphalt cements. The coefficients of variation of the original asphalt cements for the twenty-two similar samples were very stable ranging from 3.15 to 4.27 percent. The gradual declining slope of the line connecting the coefficients of variation for the thin film residues indicates improvement in test precision during this period.

The third segment of the graph plots the coefficients of varlation for nine pairs of asphalt cements. The pairs distributed during this period varied considerably in grade and source. As a result, the coefficients of variation for both the original asphalt cements and the thin film residues are generally larger than those at the end of the second segment.

The ASTM multilaboratory one-sigma precision limit in percent (1S\%) for the penetration at $25^{\circ} \mathrm{C}$ of asphalt cements above fifty penetration units, given in ASTM D5 [8], is 2.8 percent. Except for six coefficients of variation in the first segment of the graph, all values are larger than the ASTM precision estimate. In general, the values are within one unit of the precision criteria.

An estimate of the test precision for the penetration of thin film residues is not provided in ASTM D1754.

\subsection{Continuous ys Limited Participation}

Figure 6 compares the coefficients of variation of the kinematic viscosity of asphalt cements at $135^{\circ} \mathrm{C}$ for continuous and limited participation groups. The individual laboratories comprising the continuous participation group performed the kinematic viscosity test on 80 percent or more of the asphalt cement samples since the beginning of the program. The limited or discontinuous participation group tested fewer samples.

The plot of the continuous participation group shows declining coefficients of variation during the first five years of the program (1966-1971). After 1971. the coefficients of variation varied between 1 and 3 percent for the remainder of the program. Except for three cases the coefficients of variation for the continuous participation group were lower than those for the limited participation group, implying that consistant participation improves test precision.

The ASTM multilaboratory one-sigma precision limit in percent (1S\%) for the kinematic viscosity of asphalt cements at $135^{\circ} \mathrm{C}$, given in ASTM D2170 [9], is 3.1 percent. The graph indicates that the test precision for the continuous participation group is usually better than the ASTM precision estimate while the limited participation group, since 1975, performed much closer to the ASTM precision criteria. 


\subsection{Coefficients of Varfation for Cutback Asphalts}

Figure 7 shows the coefficients of variation obtained from the viscosity tests performed on original cutback asphalts and distillation residues. Three sets of points are plotted, one for the kinematic viscosity of the original cutback asphalt, another for the kinematic viscosity of the distillation residue at $135^{\circ} \mathrm{C}$, and a third for the viscosity of the distillation residue at $60^{\circ} \mathrm{C}$. The eighteen cutback asphalts analyzed were distributed to participants between 1973 and 1980 as shown in Table 1. The ranges in the coefficients of variation for the eighteen samples were:

1) 1.5 to 5 percent for the kinematic viscosity at $60^{\circ} \mathrm{C}$ on original.

2) 6 to 10 percent for kinematic viscosity at $135^{\circ} \mathrm{C}$ on residue.

3) 12 to 21 percent for vacuum viscosity at $60^{\circ} \mathrm{C}$ on residue.

The ASTM multilaboratory one-sigma precision limit in percent (1S\%) for liquid asphalts at $60^{\circ} \mathrm{C}$ having a viscosity below 3000 centistokes $\left(0.003 \mathrm{M}^{2} / \mathrm{S}\right)$, given in ASTM D2170, is 1.06 percent. This estimate appears to be too low. The ASTM Test Method D402 [10] gives no criteria for judging the viscosity tests on distillation residues, however, the values plotted in Figure 7 could serve as a means of estimating multilaboratory precision. 
The Bituminous Reference Sample Program serves the needs of the AMRL sponsors and the participating laboratories.

The benefits include:

1. A means of checking both instrument and operator under actual testing conditions.

2. A means of comparing individual test results with the average of a large body of results so that corrective action may be taken where wide discrepancies in test results occur.

3. A means of evaluating the quality of the individual measurement, thereby reducing the risk of dispute due to testing errors.

4. A means of furnishing documentation of testing capabilities.

5. Improved reliability of asphalt cement and cutback asphalt test measurements, and

6. Better definition of the precision of standard methods of test.

Providing these services is one way the AMRL meets its primary responsibility of promoting uniformity in the testing of construction materials and the quality of test results. 


\section{CONCLUSIONS}

1. The individual laboratory ratings on a pair of reference samples provide a good indication of the accuracy of laboratory test results.

2. The laboratory performance charts provide a method of demonstrating a laboratory's testing capabilities.

3. The coefficients of variation for the viscosity at $60^{\circ} \mathrm{C}$ of $\mathrm{AC}-20$ graded asphalt cements and thin film residues indicate that the precision of participating laboratories has improved since 1972.

4. As illustrated by the test for the kinematic viscosity of asphalt cements at $135^{\circ} \mathrm{C}$, the precision of results is generally better for laboratories that participate continuously in the bituminous reference sample program than for those that participate infrequently.

5. Coefficients of variation for the penetration and viscosity of thin film oven and distillation residues are higher and more variable than those for the original asphalt cements and cutback asphalts.

6. A review of the coefficients of variation obtained from tests performed on asphalt cement and cutback asphalt reference samples provides a useful means of evaluating established multilaboratory precision limits or determining test precision where estimates do not yet exist. 


\section{REFERENCES}

[1] Page, L. W., "Standard Forms for Specifications, Test, Reports, and Methods of Sampling for Road Materials", U. S. Department of Agriculture Bulletin No. 555, Nov. 1917.

[2] Steele, G. W., "The AASHTO Materials Reference Laboratory - Fifteen Years of Service", AASHTO, Vol. 60, No. 1, 1981, p.35.

[3] Youden, W. J., "Statistical Aspects of the Cement Testing Program", Proceedings, American Society for Testing and Materials, Vo1. 59, 1959, p. 1120.

[4] Crandall, J. R. and Blaine, R. L., "Statistical Evaluation of Interlaboratory Cement Tests", Proceedings, American Society for Testing and Materials, Vol. 59, 1959, p. 1129.

[5] ASTM C670, Standard Practice for Preparing Precision Statements for Test Methods for construction Materials, Annual Book of Standards, Parts 13, 14, 17 and 19, American Society for Testing and Materials, 1916 Race Street, Philadelphia, PA 19103.

[6] ASTM D2171, Standard Test Method for Viscosity of Asphalts by Vacuum Capillary Viscometer, Annual Book of Standards, Part 15, American Society for Testing and Materials, 1916 Race Street, Philadelphia, PA 19103.

[7] ASTM D1754, Standard Test Method for Effect of Heat and Air on Asphaltic Materials (Thin Film Oven Test), Annual Book of Standards, Part 15, American Society for Testing and Materials, 1916 Race Street, Philadelphia, PA 19103.

[8] ASTM D5, Standard Test Method for Penetration of Bituminous Materials, Annual Book of Standards, Part 15, American Society for Testing and Materials, 1916 Race Street, Philadelphia, PA 19103.

[9] ASTM D2170, Standard Test Method for Kinematic Viscosity of Asphalts (Bitumens), Annual Book of Standards, Part 15, American Society for Testing and Materials, 1916 Race Street, Philadelphia, PA 19103

[10] ASTM D402, Standard Test Method for Distillation of Cut-Back Asphaltic (Bituminous) Products, Annual Book of Standards, Part 15, American Society for Testing and Materials, 1916 Race Street, Philadelphia, PA 19103. 
TABLE 1

BITUMINOUS REFERENCE SAMPLE PROGRAM PARTICIPATION

FROM 1966 TO 1982

\begin{tabular}{|c|c|c|c|c|c|c|c|c|c|}
\hline $\begin{array}{c}\text { Sample } \\
\text { Nos. }\end{array}$ & $\begin{array}{l}\text { Mate- } \\
\text { rial }\end{array}$ & Grade & $\begin{array}{c}\text { Date } \\
\text { Distributed }\end{array}$ & State & $\begin{array}{l}\text { Fed- } \\
\text { eral }\end{array}$ & $\begin{array}{l}\text { Pro- } \\
\text { ducer }\end{array}$ & $\begin{array}{c}\text { Commer- } \\
\text { cial }\end{array}$ & $\begin{array}{l}\text { Miscel- } \\
\text { laneous }\end{array}$ & Total \\
\hline 01 & $\mathrm{AC}$ & $85 / 100$ & & & & & & & \\
\hline 02 & $\overline{A C}$ & $200 / 300$ & $05 / 66$ & 52 & 1 & -- & -- & -- & 53 \\
\hline 03 & $\mathrm{AC}$ & $85 / 100$ & & & & & & & \\
\hline 04 & $\mathrm{AC}$ & $60 / 70$ & $01 / 67$ & 52 & 1 & -- & -- & -- & 53 \\
\hline $05 \& 06$ & $\overline{A C}$ & $85 / 100$ & $03 / 67$ & 57 & 1 & $=$ & -- & 1 & 59 \\
\hline $07 \& 08$ & $C B$ & $M C-250$ & $08 / 67$ & 59 & 3 & - & -- & 1 & 63 \\
\hline $\begin{array}{l}09 \& 10 \\
\end{array}$ & $\mathrm{CB}$ & $\mathrm{MC}-250$ & $03 / 68$ & 59 & 3 & - & $=$ & 1 & 63 \\
\hline $11 \& 12$ & $C B$ & $\mathrm{MC}-30$ & $09 / 68$ & 59 & 3 & 2 & 1 & 1 & 66 \\
\hline $13 \& 14$ & $\mathrm{CB}$ & $\mathrm{RC}-250$ & $03 / 69$ & 66 & 4 & 2 & 1 & 1 & 74 \\
\hline 15 & $\overline{A C}$ & $85 / 100$ & & & & & & & \\
\hline 16 & $\mathrm{AC}$ & $60 / 70$ & $09 / 69$ & 66 & 7 & 2 & 1 & 1 & 77 \\
\hline $17 \& 18$ & $\mathrm{AC}$ & $120 / 250$ & $03 / 70$ & 66 & 7 & 2 & 1 & 1 & 77 \\
\hline 19 & $\mathrm{AC}$ & $120 / 250$ & & & & & & & \\
\hline 20 & $\mathrm{AC}$ & $200 / 300$ & $09 / 70$ & 66 & 7 & 2 & 1 & 1 & 77 \\
\hline $21 \& 22$ & $\overline{\mathrm{AC}}$ & $120 / 150$ & $03 / 71$ & 66 & 9 & 15 & 30 & 2 & 122 \\
\hline $23 \& 24$ & $\mathrm{AC}$ & $200 / 300$ & $09 / 71$ & 66 & 9 & 15 & 29 & 2 & 121 \\
\hline $25 \& 26$ & $\mathrm{AC}$ & $85 / 100$ & $03 / 72$ & 66 & 9 & 29 & 21 & 3 & 128 \\
\hline $27 \& 28$ & $\mathrm{AC}$ & $A C-20$ & $09 / 72$ & 66 & 9 & 29 & 17 & 2 & 123 \\
\hline $29 \& 30$ & $\mathrm{AC}$ & $A C-20$ & $03 / 73$ & 66 & 11 & 26 & 17 & 1 & 121 \\
\hline $31 \& 32$ & $C B$ & $M C-250$ & $06 / 73$ & 65 & 8 & 19 & 18 & 3 & 113 \\
\hline $33 \& 34$ & $\mathrm{AC}$ & $\mathrm{AC}-20$ & $06 / 73$ & 66 & 9 & 25 & 17 & - & 117 \\
\hline $35 \& 36$ & $\mathrm{AC}$ & $A C-20$ & $03 / 74$ & 75 & 6 & 28 & 14 & 3 & 126 \\
\hline $37 \& 38$ & $\mathrm{CB}$ & $M C-250$ & $06 / 74$ & 75 & $\frac{6}{6}$ & 21 & 8 & $\frac{2}{2}$ & 112 \\
\hline $39 \& 40$ & $\mathrm{AC}$ & $85 / 100$ & $09 / 74$ & 76 & 6 & 23 & 12 & 2 & 119 \\
\hline $41 \& 42$ & $A C$ & $\mathrm{AC}-20$ & $03 / 75$ & 76 & $\frac{7}{7}$ & 20 & 11 & 4 & 118 \\
\hline $43 \& 44$ & $\mathrm{CB}$ & MC-250 & $06 / 75$ & 76 & 7 & 17 & 7 & 3 & 110 \\
\hline $45 \& 46$ & $\mathrm{AC}$ & $85 / 100$ & 09175 & 78 & 7 & 19 & 5 & 4 & 115 \\
\hline $47 \& 48$ & $\mathrm{AC}$ & $\mathrm{AC}-20$ & $03 / 76$ & 79 & 7 & 22 & 10 & 4 & 122 \\
\hline $49 \& 50$ & $\mathrm{CB}$ & MC- 250 & $06 / 76$ & 79 & 6 & 18 & $\frac{-7}{7}$ & 3 & 113 \\
\hline $51 \& 52$ & $\overline{A C}$ & $\mathrm{AC}-20$ & $09 / 76$ & 78 & 7 & 21 & 11 & 4 & 121 \\
\hline $53 \& 54$ & $\overline{A C}$ & $\mathrm{AC}-20$ & $03 / 77$ & 78 & 7 & 22 & 8 & 4 & 119 \\
\hline $55 \& 56$ & $C B$ & $M C-250$ & $06 / 77$ & 75 & 6 & 18 & 5 & 3 & 108 \\
\hline $57 \& 58$ & $\mathrm{AC}$ & $\mathrm{AC}-10$ & $09 / 77$ & 78 & 7 & 22 & 9 & 5 & 121 \\
\hline $59 \& 60$ & $\mathrm{AC}$ & $A C-20$ & $03 / 78$ & 79 & 7 & 25 & 9 & $\frac{6}{6}$ & 126 \\
\hline $61 \& 62$ & $\mathrm{CB}$ & $M C-250$ & $06 / 78$ & 76 & 6 & 22 & 5 & 3 & 112 \\
\hline $63 \& 64$ & $\mathrm{AC}$ & AR-20 & $09 / 78$ & 76 & 7 & 25 & 5 & $\frac{5}{6}$ & 123 \\
\hline $65 \& 66$ & $\mathrm{AC}$ & $A C-20$ & $03 / 79$ & 72 & 9 & 26 & 11 & 5 & 123 \\
\hline $67 \& 68$ & $C B$ & $M C-250$ & $06 / 79$ & 74 & $\frac{7}{6}$ & 21 & $\frac{-7}{7}$ & 3 & 113 \\
\hline $69 \& 70$ & $\mathrm{AC}$ & $\mathrm{AC}-10$ & $09 / 79$ & 72 & 7 & 26 & 11 & 5 & 121 \\
\hline $71 \& 72$ & $A C$ & $A C-20$ & $03 / 80$ & 72 & 7 & 27 & 13 & $\frac{5}{6}$ & 125 \\
\hline $73 \& 74$ & $\mathrm{CB}$ & $M C-70$ & $06 / 80$ & 65 & 7 & 22 & 15 & 5 & 114 \\
\hline $75 \& 76$ & $\overline{A C}$ & $A C-20$ & $09 / 80$ & 65 & 7 & 28 & 18 & 6 & 126 \\
\hline $77 \& 78$ & $\mathrm{AC}$ & $\mathrm{AR}-20$ & $03 / 81$ & 65 & 8 & 32 & 17 & 10 & 132 \\
\hline $79 \& 80$ & $\mathrm{CB}$ & $M C-250$ & $06 / 81$ & 65 & 7 & 27 & 18 & 10 & 127 \\
\hline $81 \& 82$ & $\mathrm{AC}$ & $\mathrm{AC}-20$ & $09 / 81$ & 65 & 8 & 32 & 17 & 10 & 132 \\
\hline
\end{tabular}




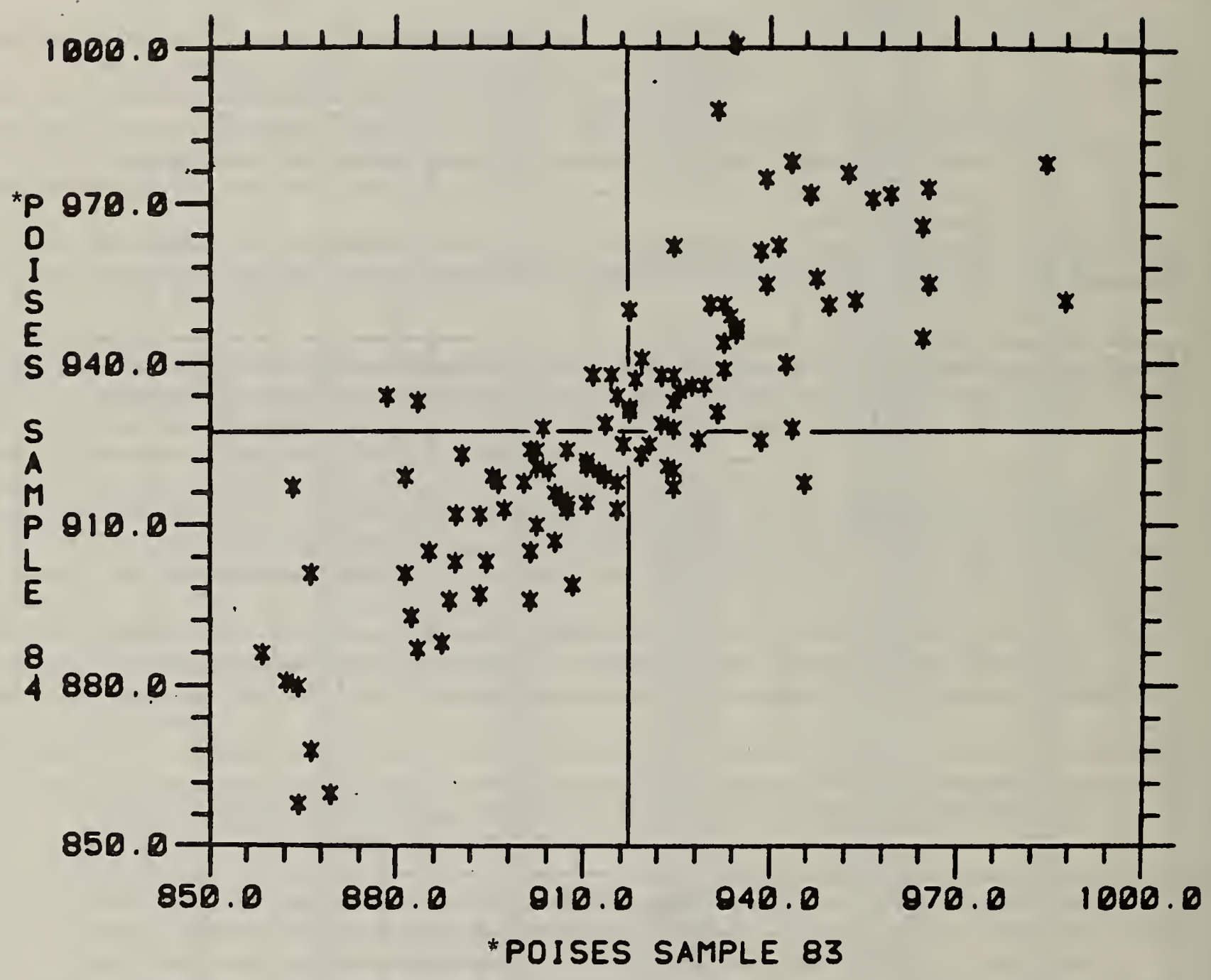

FICURE 1 - YOUDEN SCATTER DIAGRAM FOR VISCOSITY AT GOC

*NOTE: The SI unit of viscosity is $I \mathrm{~Pa} \cdot \mathrm{s}\left(1 \mathrm{~N} \cdot \mathrm{s} / \mathrm{m}^{2}\right)$ and is equivalent to 10 poises. 

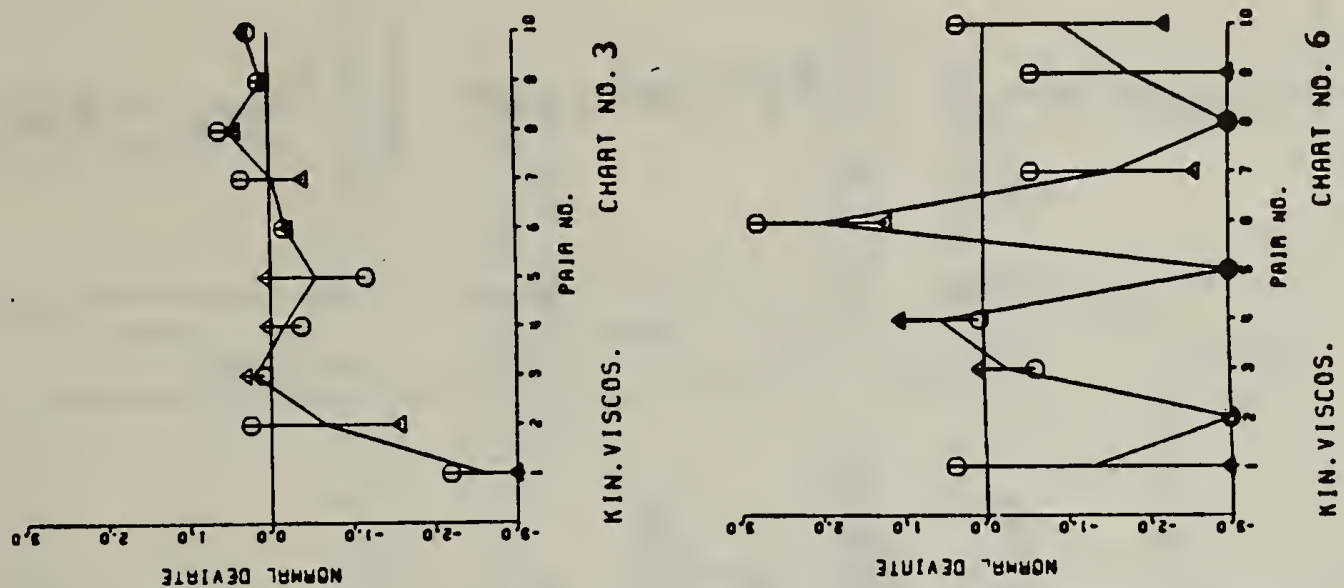

ש
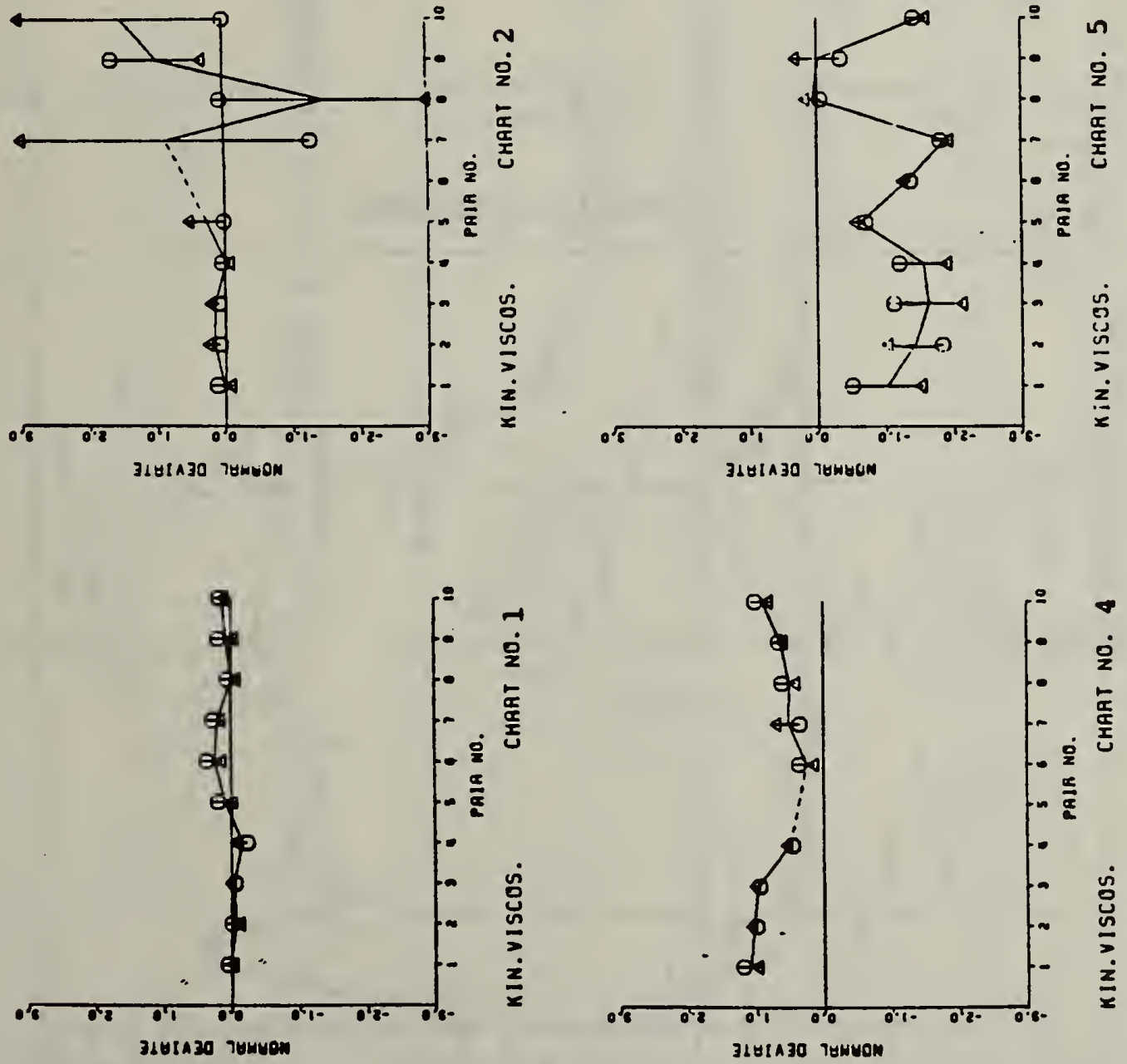

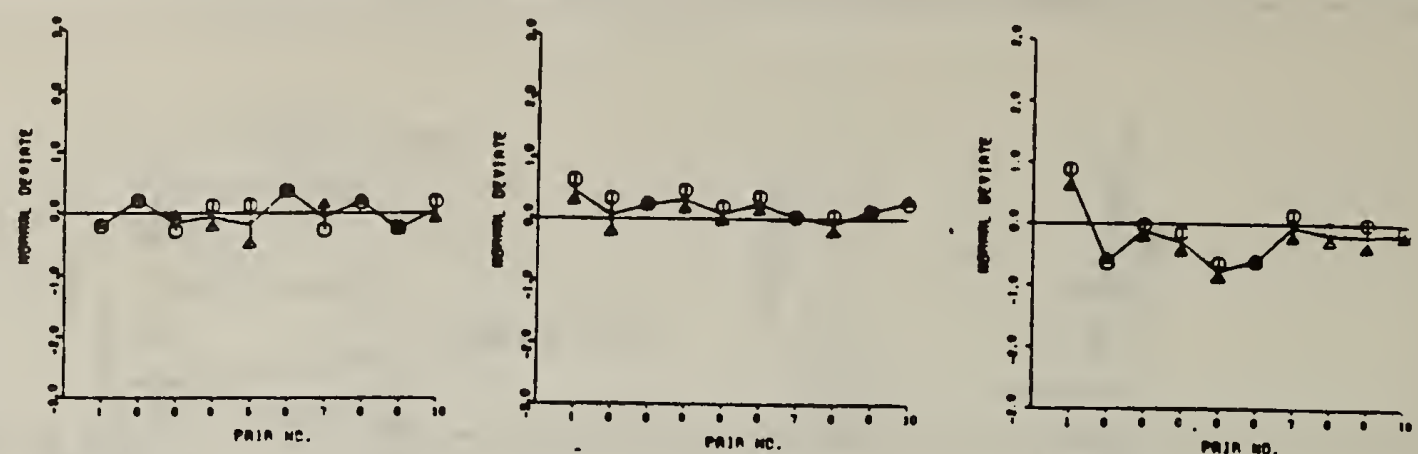

MIN.visces.

ABS. viscos.
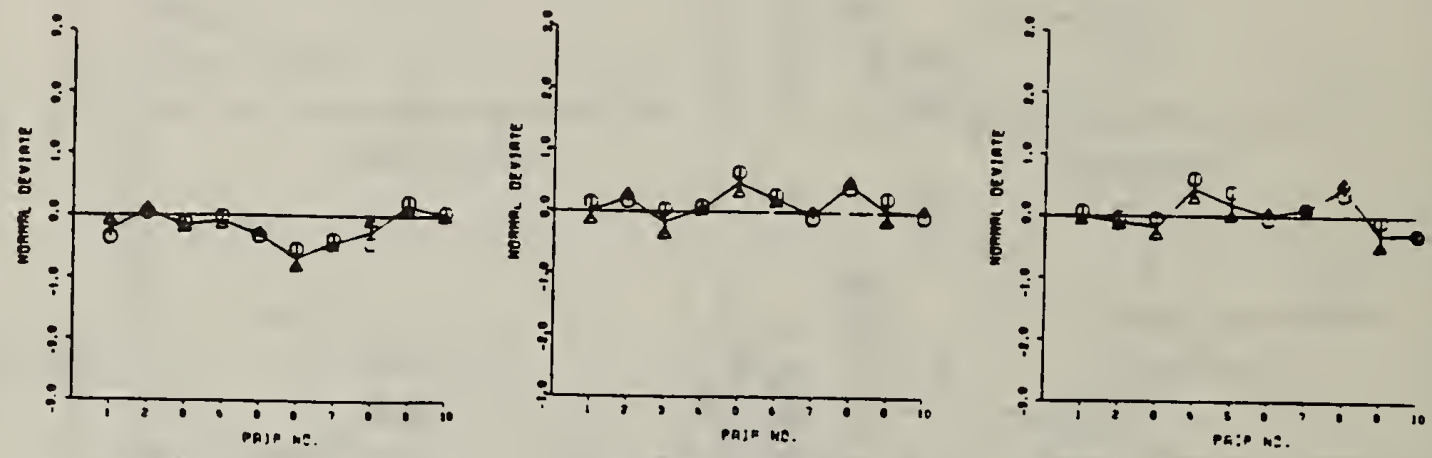

A日S VIS PES

IABORATORY A - GOOD CONTROL
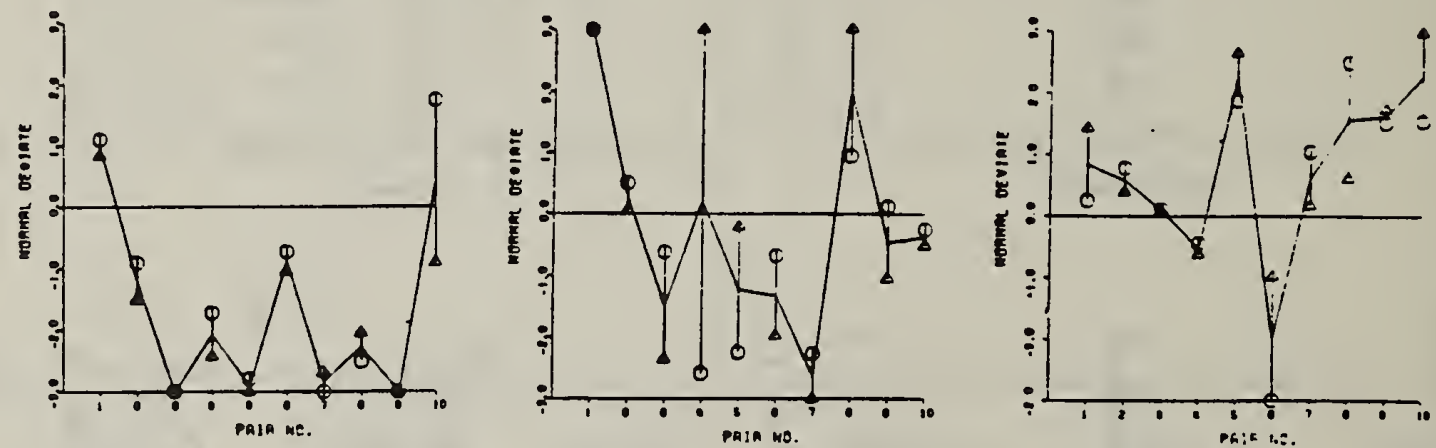

ORIC PENETA

RIN.viscos.

ARs.visess.
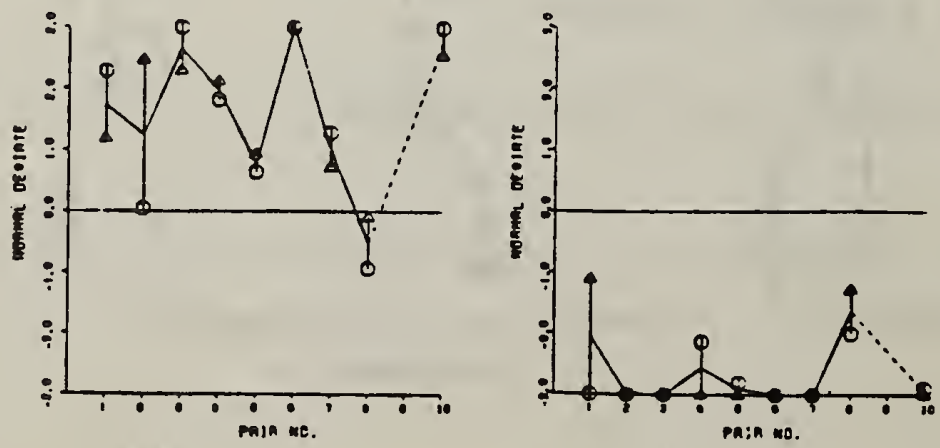

MiN VIS RES

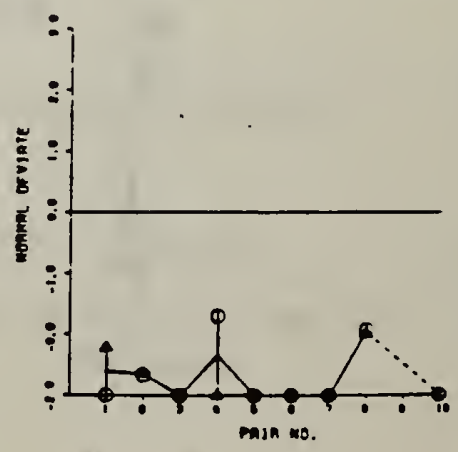

ABS VIS RES

LABORATORY B - POOR CONTROL

FIGURE 3 - PERFORMANCE CHARTS FOR SIX TEST PROPERTIES OBTAINED FROM TWO DIFFERENT LABORATORIES. THE RESULTS OF LABORATORY A INDICATE GOOD TESTING CONTROL; THE RESULTS OF LABORATORY B INDICATE POOR PERFORMANCE. 


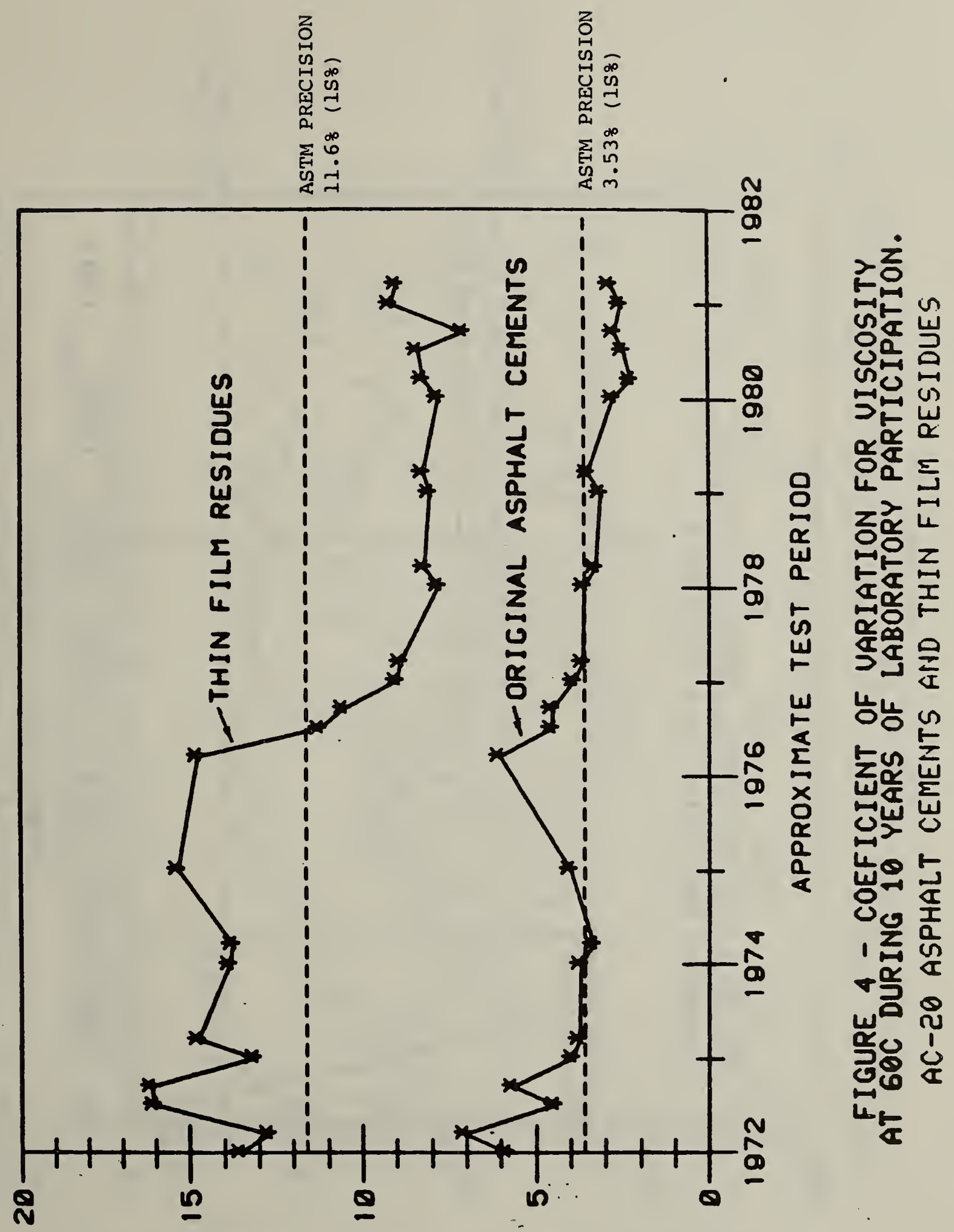

vOWLL OU $><\alpha n<R-0 Z$ * 


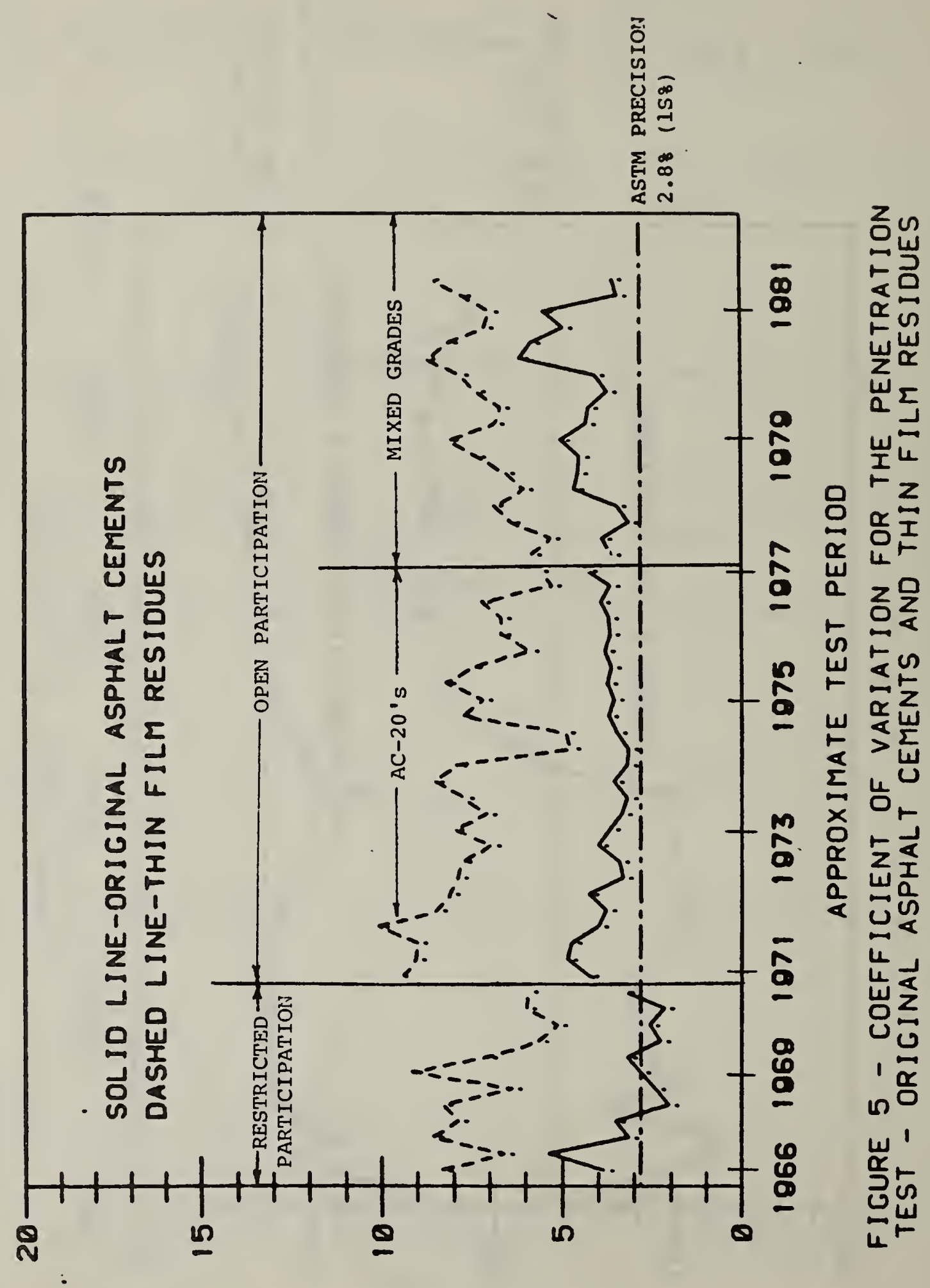

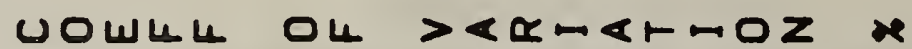




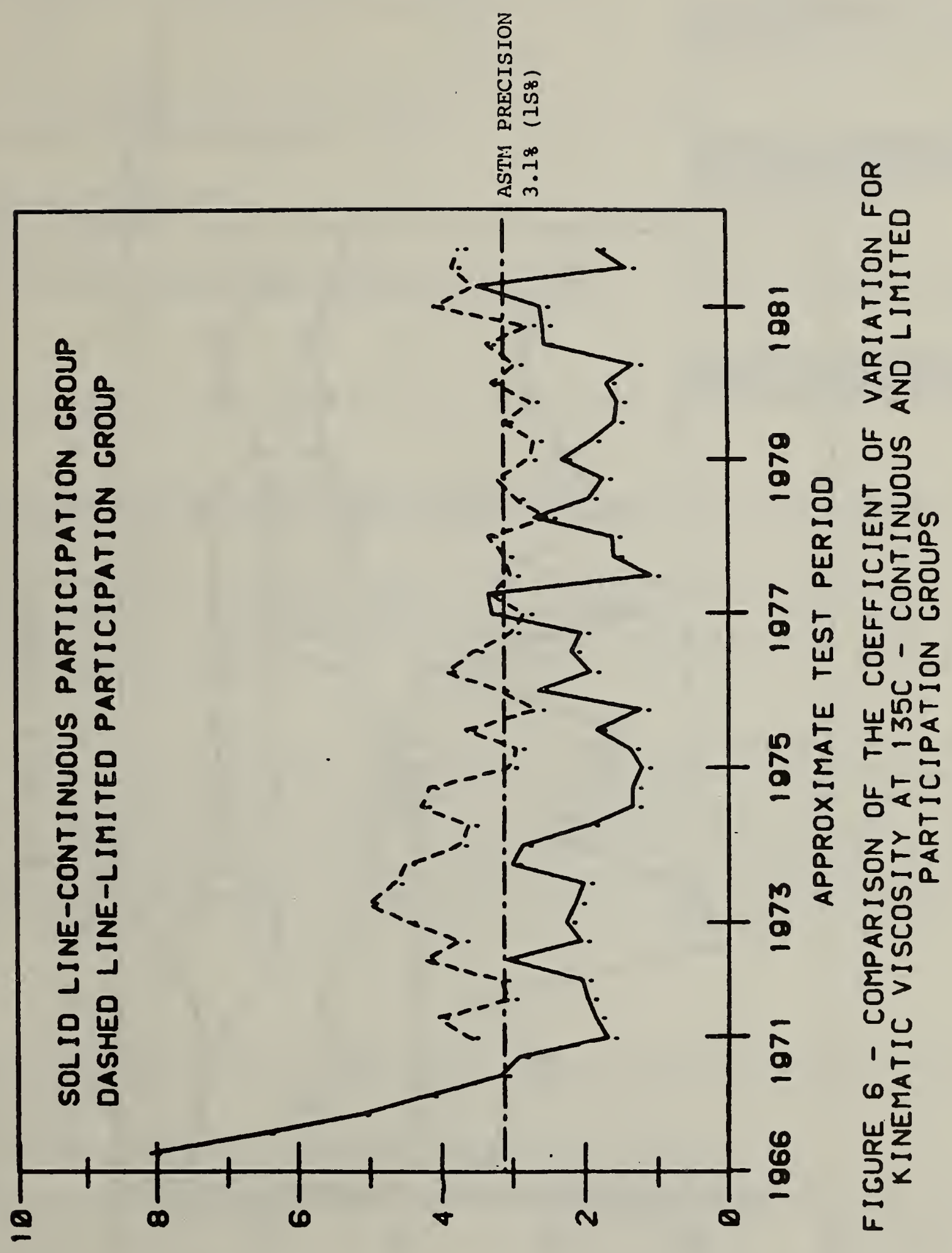

vowhl OH $><0 m<\leftarrow-O Z$ * 


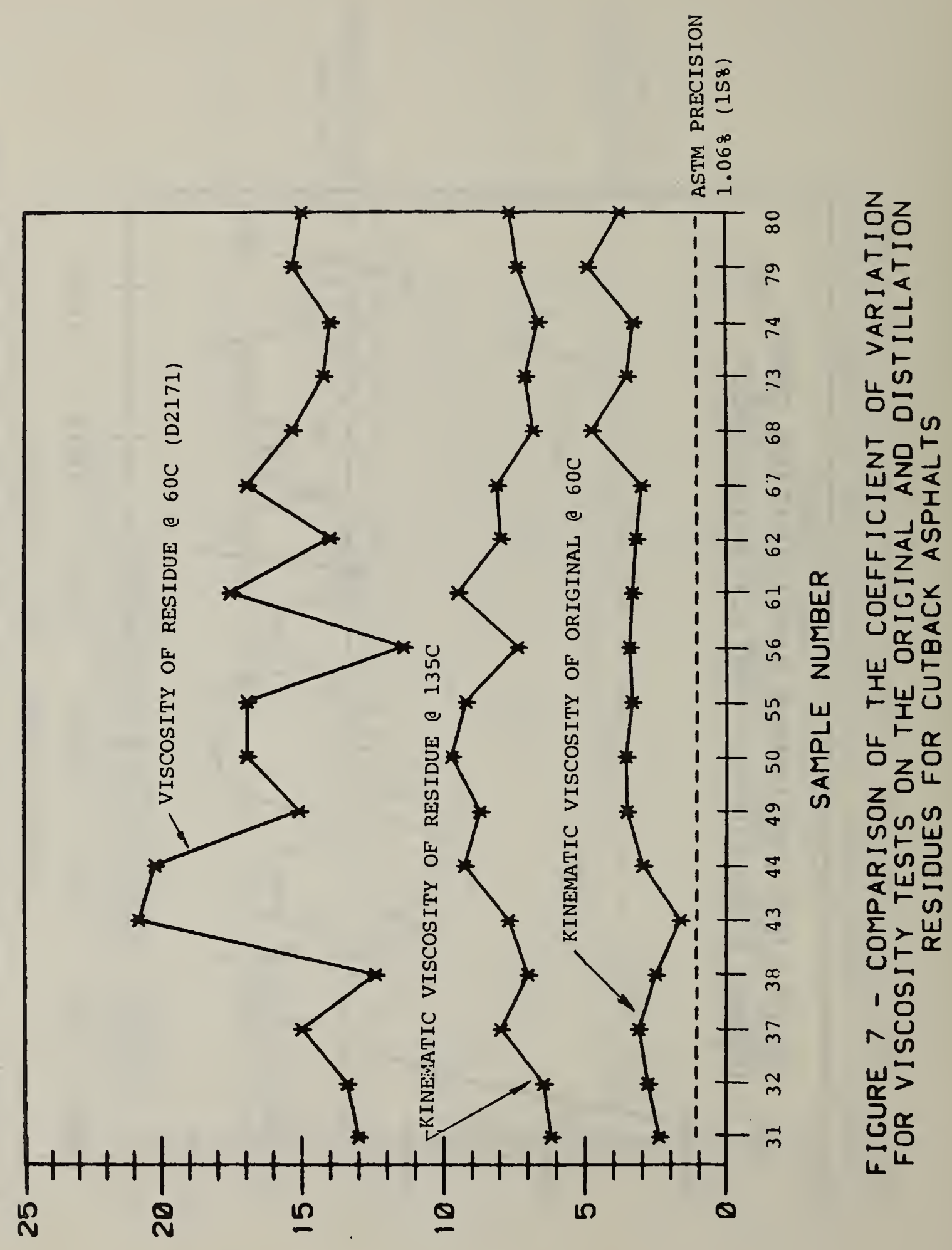

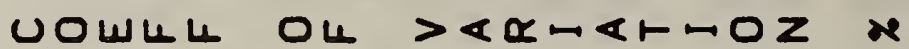




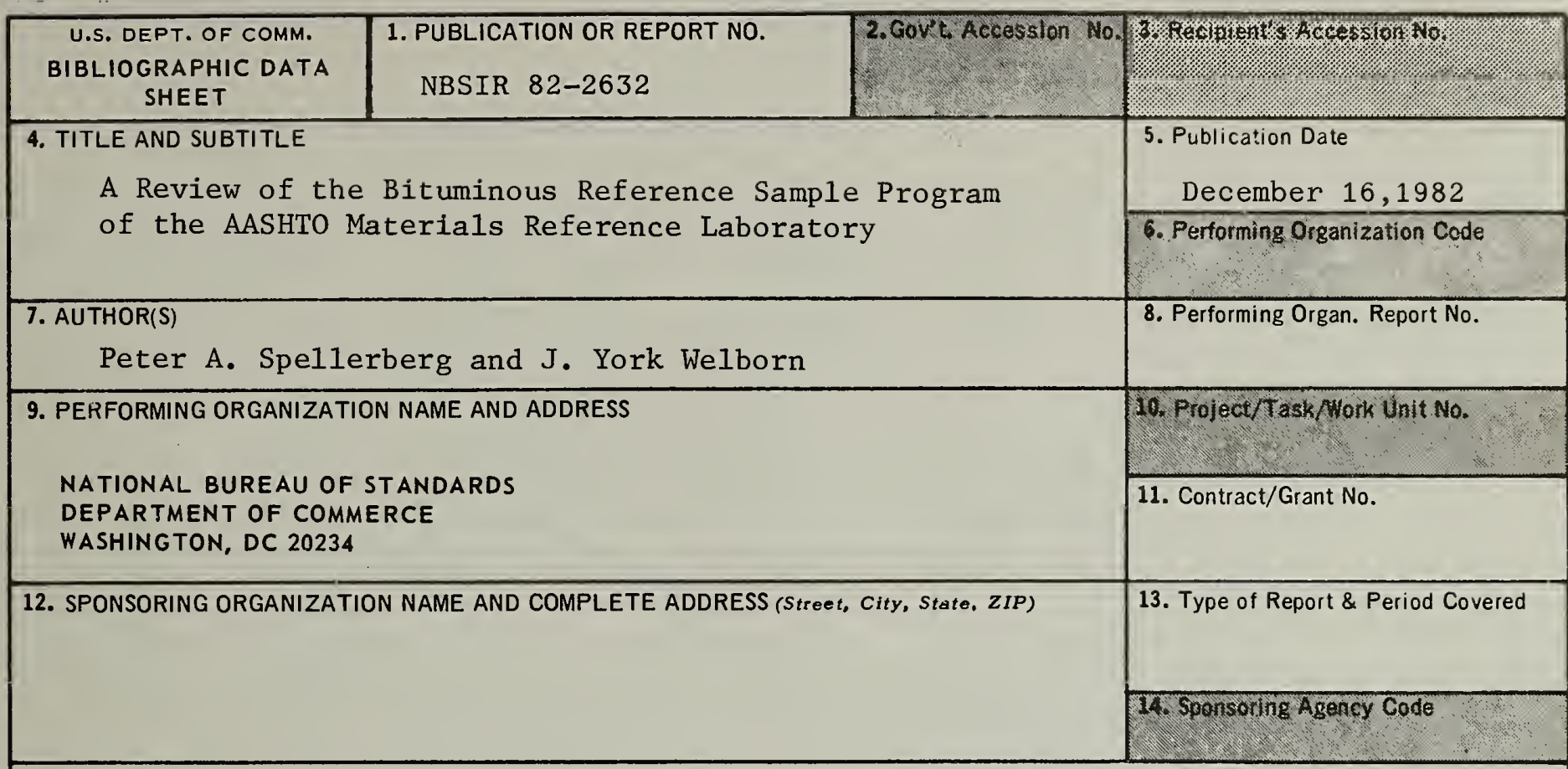

15. SUPPLEMENTARY NOTES

Document describes a computer program; SF-185, FIPS Software Summary, is attached.

16. ABSTRACT (A 200-word or less factual summary of most significant information. If document includes a significant bibliography or literature survey, mention it here.)

The Bituminous Reference Sample Program of the AASHTO Materials Reference Laboratory has been operating for more than fifteen years. This paper provides an overview of the accomplishments of this important cooperative undertaking of the National Bureau of Standards and the American Association of State Highway and Transportation Officials.

Background information on the development of standard specifications and methods of test, the AASHTO and the AMRL, is presented to give a historical perspective and to identify the need for the program. Details concerning its operation are reviewed. The coefficients of variation derived from the analysis of laboratory test data from a number of selected tests are plotted and evaluated. The value of the laboratory rating system and the laboratory performance charts which have been developed is discussed. Conclusions are made regarding the effectiveness of the program and the accuracy of established test precision limits.

17. KEY WORDS (six to twelve entries; alphabetical order; capitalize only the first letter of the first key word unless a proper name; separated by semicolons)

Test Precision, Laboratory Performance, Coefficient of Variation

18. AVAILABILITY $\square$ Unlimited

XX For Official Distribution. Do ivot Release to NTIS

$\square$ Order From Sup. of Doc., U.S. Government Printing Office, Wasinington, DC 20402, SD Stock No. SNÖ03-003-

Order From National Technical Information Service (NTIS), Springfield, VA. 22161

\begin{tabular}{|l|c|}
\hline $\begin{array}{l}\text { 19. SECUR!TY CLASS } \\
\text { (THIS REPORT) }\end{array}$ & $\begin{array}{c}\text { 21. NO. OF } \\
\text { PRINTED PAGES } \\
\text { UNCLASSIFIED }\end{array}$ \\
\hline $\begin{array}{l}\text { 20. SECURITY CLASS } \\
\text { (THIS PAGE) }\end{array}$ & 24. Price \\
UNCLASSIFIED & $\$ 7.00$ \\
\hline
\end{tabular}




